\title{
KUALITAS LAYANAN INFORMASI DI KANTOR PUSAT INFORMASI PENGEMBANGAN PERMUKIMAN DAN BANGUNAN (PIP2B) PROVINSI KALIMANTAN TENGAH
}

\section{Quality of Information Service at Information Center of Settlement and Building Development of Central Kalimantan Province}

\section{Mambang* \\ Ratna Indah Setyowati}

Universitas Muhammadiyah Palangkaraya, Palangka Raya, Central Kalimantan, Indonesia

email:

mambang@umpalangkaraya.ac.id

Kata Kunci:

Kualitas Pelayanan

Sarana Prasarana

Layanan Informasi

\section{Keywords:}

Quality of Service

Infrastructure

Information Service

\begin{abstract}
Abstrak
Pusat Informasi Pengembangan Permukiman dan Bangunan (PIP2B) adalah lembaga inovatif yang ditargetkan untuk menjadi lembaga publik yang mendukung penyelenggaraan perumahan dan permukiman. Yang dalam pembentukannya difasilitasi Pemerintah Pusat dan menjadi milik Dinas Pekerjaan Umum Pemerintah Provinsi Kalimantan Tengah. Dalam mendukung penyelenggaraan perumahan dan permukiman, Pusat Informasi Pengembangan Permukiman dan Bangunan Gedung (PIP2B) memberikan kemudahan layanan dan akses untuk mendapatkan informasi kepada berbagai unsur: perencana, pelaksana, pengusaha bahan bangunan, pihak pemerintah, masyarakat serta kalangan akademisi. Penelitian ini dilatarbelakangi oleh banyaknya keluhan dari masyarakat Kota Palangka Raya mengenai Layanan informasi di Pusat Informasi Pengembangan Permukiman dan Bangunan (PIP2B) masih belum dapat dirasakan oleh masyarakat secara merata.

Jenis Penelitian yang digunakan adalah penelitian deskriptif kualitatif. Teknik pengumpulan data pada penelitian ini menggunakan teknik observasi, wawancara, dan dokumentasi. Teknik analisa data menggunakan langkah-langkah yaitu dengan langkah reduksi data, penyajian data dan kesimpulan akhir. Sedangkan untuk keabsahan data peneliti menggunakan triangulasi yaitu dengan cara membandingkan data yang diperoleh dari hasil wawancara antara informan penelitian dengan informan penelitian yang lain.
\end{abstract}

Hasil penelitian menunjukan bahwa berdasarkan hasil wawancara dan dokumentasi penelitian dengan indikator Tangible, realibility, Responsiviness, Assurance dan Empati serta juga dikaitkan dengan indikator pelayanan maka dapat diambil beberapa kesimpulan diantaranya terlihat dari banyaknya temuan penelitian di lapangan baik karena faktor sarana dan prasarana yang masih belum memadai terlihat minimnya fasilitas yang diberikan, serta komunikasi yang kurang terjalin antara pihak Kantor Pusat Informasi Pengembangan Permukiman dan Bangunan (PIP2B) dengan Kementerian PUPR.

\begin{abstract}
The Residential and Building Development Information Center (PIP2B) is an innovative institution that is targeted to become a public institution that supports the implementation of housing and settlements. Which in its establishment is facilitated by the Central Government and belongs to the Provincial Public Works Department of Central Kalimantan. In support of housing and settlement operations, the Settlement and Building Development Information Center (PIP2B) provides ease of services and access to information on various elements: planners, implementers, building materials entrepreneurs, government, communities and academics. This research is motivated by the many complaints from Palangka Raya City community about Information Service in Information Center of Settlement and Building Development (PIP2B) still can not be felt by society evenly.

Type of research used is descriptive qualitative research. Research that aims to describe and describe events and phenomena that occur in the field and presents data in a systematic, factual, and accurate about the facts or phenomena that occur in the field. Data collection techniques in this study using observation techniques, interviews, and documentation. Technique of data analysis using steps that is with data reduction step, data presentation and final conclusion. While for data validity of researcher use triangulation that is by comparing data obtained from interview result between research informant with other research informant.
\end{abstract}

The results showed that based on the results of interviews and research documentation with Tangible indicator, realibility, Responsiveness, Assurance and Empathy as well as related to service indicators, it can be drawn some conclusions as seen from the many rocoarch findinas in tho fiold aithor duo to inadoaunto facilitioc and infractructurs tho lack 


\section{PENDAHULUAN}

Informasi merupakan kebutuhan pokok setiap orang bagi pengembangan pribadi dan lingkungan sosialnya serta merupakan bagian penting bagi ketahanan nasional. Keberadaan informasi semakin diperlukan dalam meningkatkan kualitas pelayanan dan juga pelibatan masyarakat dalam proses pengambilan keputusan publik dalam pembangunan. Salah satu sumber atau penyedia informasi publik tentang pembangunan tersebut adalah Kantor Pusat Informasi Pengembangan Permukiman dan Bangunan (PIP2B) Provinsi Kalimantan Tengah.

Layanan informasi merupakan salah satu bentuk layanan yang diberikan dalam memasarkan, memperkenalkan sebuah produk atau jasa, penyampaian informasi yang akurat sangat dibutuhkan sebagai sarana peningkatan pelayanan yang diberikan oleh suatu lembaga atau organisasi baik itu dalam pemerintahan atau swasta, dengan penyampaian informasi secara akurat dalam hal ini kebenaran atas informasi dapat meningkatkan rasa kepercayaan dan kenyamanan dari konsumen kepada pihak yang menyebarkan informasi (Soegijoko, 2010). Sedangkan Kualitas dapat diartikan mampu memberi sesuatu yang berbeda untuk orang yang berbeda. Kualitas merupakan totalitas penampilan dan karakteristik produk atau pelayanan yang memberi kepuasan atau mampu memenuhi kebutuhan. Mendefinisikan harapan terhadap kualitas merupakan hal kritis dalam manajemen operasional secara efektif dan efisien (Heizer et al., 2014).

Direktorat Jenderal Cipta Karya, mengarahkan pengembangan PIP2B sebagai lembaga yang inovatif melayani kebutuhan dalam penyelenggaraan pembangunan baik untuk kepentingan pemerintah maupun pemerintah daerah serta masyarakat. Untuk kepentingan operasional, PIP2B dibentuk di tingkat Provinsi. PIP2B memiliki tugas, fungsi dan peran sebagai center of excellence (pusat keunggulan) serta pusat rujukan teknis yang dapat diandalkan di daerah.
Pusat Informasi Pengembangan Permukiman dan Bangunan (PIP2B) merupakan lembaga inovatif yang ditargetkan untuk menjadi lembaga publik yang mendukung penyelenggaraan perumahan dan permukiman. Yang dalam pembentukannya difasilitasi Pemerintah Pusat dan menjadi milik Dinas Pekerjaan Umum Pemerintah Provinsi dalam mendukung penyelenggaraan perumahan dan permukiman, Pusat Informasi Pengembangan Permukiman dan Bangunan Gedung (PIP2B) memberikan kemudahan layanan dan akses untuk mendapatkan informasi kepada berbagai unsur: perencana, pelaksana, pengusaha bahan bangunan, pihak pemerintah, masyarakat serta kalangan akademisi. Salah satu tujuan yaitu penyediaan akses dan layanan informasi teknologi, perolehan layanan konsultasi dan advokasi serta peningkatan kapasitas dan kompetensi pelaku penyelenggaraan pembangunan di bidang Cipta Karya.

\section{METODOLOGI}

Dalam penelitian ini menggunakan metode penelitian deskritif kualitatif, karena peneliti disini didalamnya terdapat upaya mendeskrifsikan apa yang terjadi pada saat melakukan penelitian, mencatat, menganalisa dan menginterprestasikan kondisi-kondisi yang sekarang ini terjadi atau ada. Metode penelitian kualitatif yang digunakan untuk maksud deskriptif atau memaparkan suatu objek masalah ini bertujuan untuk menjelaskan, mengungkapkan dan untuk mendapatkan deskripsi yang tepat mengenai Upaya Peningkatan Kualitas Layanan InformasidiPusat Informasi Pengembangan Permukiman dan Bangunan (PIP2B) Provinsi Kalimantan Tengah.

\section{HASIL DAN PEMBAHASAN}

Pusat Informasi Pengembangan Permukiman dan Bangunan (PIP2B) di Provinsi Kalimantan Tengah Berdiri di tahun 2010 berada didalam Struktur Satuan Penataan Bangunan dan Lingkungan Provinsi Kalimantan Tengah. Direktorat Bina Penataan 
Bangunan Direktorat Jenderal Cipta Karya

Kementerian Pekerjaan Umum dan Perumahan Rakyat.

Dikenal sebagai Lembaga yang memberikan kemudahan layanan informasi dan akses konsultasi untuk mendapatkan informasi kepada para stakeholder bidang keciptakaryaan dalam infrastruktur pembangunan permukiman kepada masyarakat dan mendukung penyelenggaraan pembangunan. Konsultan dan masyarakat yang ingin melakukan konsultasi teknis seperti pembuatan kegiatan perencanaan dan perancangan bangunan gedung dan lingkungan,dan sebagainya harus melalui beberapa prosedur yang telah ditetapkan oleh Kantor Pusat Informasi Pengembangan Permukiman dan Bangunan (PIP2B) Provinsi Kalimantan Tengah.

Dalam penelitian ini, peneliti ingin mendeskripsikan dan menganalisis bagaimana kualitas layanan informasidi Kantor Pusat InformasiPengembangan Permukiman dan Bangunan (PIP2B) Provinsi Kalimantan Tengah dan faktor-faktor yang menghambat dalam kualitas pelayanan informasi.

I. Sarana dan Prasarana

Sarana dan prasarana yang memadai merupakan penunjang dalam memberikan pelayanan kepada masyarakat. Sarana dan prasarana yang ada pada Kantor Pusat Informasi Pengembangan Permukiman dan Bangunan(PIP2B)Provinsi Kalimantan Tengah masih kurang memadai. Hal ini seperti yang akan dijelaskan berikut ini :

a. Tidak adanya petugas keamanan parkiran yang mengatur dan menjaga parkiran kendaraan sehingga masih belum terjamin keamanannya. Hal ini apabila dikaitkan dengan teori kriteria yang digunakan untuk penilaian kualitas pelayanan publik yang mengacu pada KEPMEN PAN Nomor 8I Tahun 1993 yang dijelaskan oleh Harbani Pasolong dalam bukunya Teori Administrasi Publik (2013:135-136) yaitu indikator keamanan yang menyatakan bahwa proses hasil pelayanan dapat memberikan keamanan, kenyamanan dan kepastian hukum bagi masyarakat. Selain itu menurutZeithaml Dkk (Hardiansyah, 2011:46) bahwa kualitas pelayanan dapat diukur dari 5 dimensi diantaranya yaitu dengan dimensi Tangible yang menyatakan bahwa adanya kenyamanan tempat melakukan pelayanan.

b. kurangnya tempat duduk yang disediakan di ruang tunggu sehingga masih banyaknya masyarakat yang menunggu antrian sambil berdiri, alat pendukung kegiatan yang disediakan Kantor Pusat Informasi Pengembangan Permukiman dan Bangunan (PIP2B) Provinsi Kalimantan Tengah. Hal ini apabila dikaitkan dengan teori mengenai ukuran kualitas pelayanan yang dikemukakan oleh Fandy Tjiptono dalam bukunya Hardiansyah (2011:53) mengenai indikator Bukti langsung (Tangible) yaitu meliputi fasilitas fisik, perlengkapan, pegawai dan sarana komunikasi maka fasilitas ruang tunggu yang ada pada Kantor Pusat Informasi Pengembangan Permukiman dan Bangunan (PIP2B)Provinsi Kalimantan Tengah masih belum memadai.

c. Tempat pelayanan informasi yang tidak memiliki papan informasi dan alat penunjang yng masih minm. Hal ini apabila dikaitkan dengan teori Fandy Tjiptono dalam bukunya Hardiansyah (2011:53) dengan indikator Empati bahwa ukuran kualitas pelayanan meliputi kemudahan dalam melakukan hubungan komunikasi yang baik, perhatian pribadi dan memahami kebutuhan para pelanggan sedangkan menurut teori zeithalm dkk yaitu pengembangan dari 5 dimensi dengan indikator Comunication, bahwa kualitas pelayanan dapat diukur dari kemauan pemberi layanan untuk mendengarkan suara, 
keinginan atau aspirasi pelanggan, sekaligus kesediaan untuk selalu menyampaikan informasi baru kepada masyarakat

d. masih kurangnya micropone dan sounds system di ruang rapat serta meja dan kursi baca di perpustakaan, kamar kecil yang disediakan, masih belum maksimalnya penggunaan mesin genset dalam mendukung proses pelayanan berlangsung sehingga apabila listrik utama dari PLN padam maka proses pelayanan menjadi terhenti, kurangnya computer dan printer yang beroperasional oleh Kantor Pusat Informasi Pengembangan Permukiman dan Bangunan (PIP2B) Provinsi Kalimantan Tengah sehingga fasilitas dalam mendukung pelayanan informasi sangat minim. $\mathrm{Hal}$ ini apabila dikaitkan dengan teori Fandy Tjiptono mengenai ukuran kualitas pelayanan dengan indikator Tangible yaitu meliputi fasilitas fisik, perlengkapan, pegawai dan sarana komunikasi serta dikaitkan dengan teori konsep pelayanan prima menurut Nina Rahmayanti (2010:146) dalam bukunya manajemen Pelayanan Prima bahwa ada 5 hal pokok dalam merancang pemberian pelayanan prima yaitu indikator fasilitas-fasilitas layanan yaitu tersedianya fasilitas-fasiltas yang mendukung dalam pelayanan. Maka dalam hal ini fasilitas yang ada pada Kantor Pusat Informasi Pengembangan Permukiman dan Bangunan (PIP2B) Provinsi Kalimantan Tengah masih belum memadai.

e. Belum adanya realisasi permohonan pengadaan sarana dan prasarana yang diajukan oleh Kantor Pusat Informasi Pengembangan Permukiman dan Bangunan (PIP2B) Provinsi Kalimantan Tengah ke Kementerian Pusat. $\mathrm{Hal}$ ini menunjukkan bahwa sarana dan prasana yang ada masih kurang sehingga perlu adanya pengadaan penambahan sarana dan prasarana.

2. Pelayanan Pusat Informasi Pengembangan Permukiman dan Bangunan

$$
\text { Prosedur pelayanan dalam Pelayanan }
$$
Informasi di Kantor Pusat Informasi Pengembangan Permukiman dan Bangunan (PIP2B) Provinsi Kalimantan Tengahcukup mudah. Bahwa untuk melakukan konsultasi dan bimbingan teknis hanya memerlukan surat rekomendasi dari instansi yang bersangkutan ke Kantor Pusat Informasi Pengembangan Permukiman dan Bangunan (PIP2B) Provinsi Kalimantan Tengah dan prosedur yang dijelaskan oleh petugas pelayanan. $\mathrm{Hal}$ ini sudah sejalan dengan teori tangible dengan indikator kemudahan dalam proses pelayanan sehingga prosedur dalam pelayanan informasi diKantor Pusat Informasi Pengembangan Permukiman dan Bangunan (PIP2B) Provinsi Kalimantan Tengah sudah sesuai dengan kaidah dalam memberikan pelayanan kepada masyarakat.

Mengenai waktu penyelesaian konsultasi dan bimbingan teknis yang tidak sesuai dengan ketentuan yang berlaku pada Kantor Pusat Informasi Pengembangan Permukiman dan Bangunan (PIP2B) Provinsi Kalimantan Tengah. Hal ini apabila dikaitkan dengan konsep pelayanan prima menurut Nina Rahmayanti (2010:146) dalam bukunya Manajemen Pelayanan Prima yang mengatakan bahwa ada 5 (lima) pokok dalam rancangan pemberian pelayanan prima yaitu diantaranya mengenai Regulasi Pelayanan (service regulation) Standar Operasional Prosedur (SOP) yang menjadi tolak ukur bagi petugas pelayanan yang mencakup dasar hukum, persyaratan pelayanan, prosedur pelayanan, waktu pelayanan, biaya pelayanan serta pengaduan.

Mengenai tidak adanya kejelasan waktu penyelesaian dalam konsultasi dan bimbingan teknis yang menimbulkan banyak keluhan akan 
lamanya penanganan pada Kantor Pusat Informasi Pengembangan Permukiman dan Bangunan (PIP2B) Provinsi Kalimantan Tengah sehingga masyarakat menilai pelayanan yang diberikan tidak berkualitas. $\mathrm{Hal}$ ini tidak sejalan dengan teori kualitas pelayanan yang dikemukakan oleh zeithaml (Hardiyansyah, 2011:46) indikator Assurance (jaminan) bahwa untuk mengukur kualitas pelayanan petugas harus memberikan jaminan tepat waktu dalam pelayanan. Di samping itu menurut Surjadi (2009: 46) dalam bukunya Pengembangan Pelayanan Publik teori tentang esensi pelayanan prima menjelaskan pada dasarnya pelayanan prima mencakup empat prinsip, yaitu CETAK (Cepat, Tepat, Akurat, Berkualitas) diantaranya Pelayanan harus cepat, artinya pelanggan tidak membutuhkan waktu tunggu yang lama dan juga Pelayanan harus tepat, artinya ketepatan dalam berbagai aspek yaitu aspek waktu, biaya prosedur, sasaran, kualitas maupun kuantitas serta kompetensi petugas.

Mengenai evaluasi rutin terhadap pelayanan berdasarkan hasil wawancara dengan informan penelitian bahwa evaluasi terhadap pelayanan pernah dilakukan. Hal ini tidak sejalan dengan teori tentang konsep pelayanan prima menurut Nina Rahmayanti (2010:146) dalam bukunya Manajemen Pelayanan Prima mengenai 5 hal pokok dalam merancang pemberian pelayanan prima diantaranya yaitu budaya pemberian layanan, yang meliputi Evaluation yaitu melakukan evaluasi rutin.

\section{Faktor Penghambat dalam Meningkatkan Kualitas Pelayanan}

Faktor-faktor penghambat dalam meningkatkan kualitas pelayanan publik dalam pelayanan informasi yaitu proses penanganan dari Kementerian Pusat yang sedikit lambat merespons dengan Pusat Informasi Pengembangan Permukiman dan Bangunan (PIP2B)
Provinsi Kalimantan Tengahyang membuat masyarakat mengeluh lamanya penanganan. Dalam teori implementasi kebijakan komunikasi merupakan faktor penentu dari pelaksanaan kebijakan oleh karena itu komunikasi antar organisasi sangat diperlukan agar tujuan suatu organisasi dapat tercapai. Hal ini tidak sejalan dengan teori yang dikemukan oleh Goerge C. Edward III 1980 tentang model implementasi kebijakan yang mengatakan bahwa apa yang menjadi tujuan dan sasaran kebijakan harus diinformasikan kepada kelompok sasaran (target group) sehingga akan mengurangi distorsi implementasi. Apabila penyampaian tujuan dan sasaran suatu kebijakan tidak jelas, tidak memberikan pemahaman atau bahkan tujuan dan sasaran kebijakan tidak diketahui sama sekali oleh kelompok sasaran, maka kemungkinan akan terjadi suatu penolakan atau resistensi dari kelompok sasaran yang bersangkutan.

Dari hasil penelitian juga di dapat bahwa faktor penghambat dalam memberikan pelayanan yang berkualitas yaitu faktor sarana dan prasarana yaitu segala macam jenis peralatan, perlengkapan kerja dan fasilitas yang berfungsi sebagai alat pendukung utama dalam mempercepat pelaksanaan penyelesaiaan pekerjaan terbatas. Sarana dan prasarana yang adapada Pusat Informasi Pengembangan Permukiman dan Bangunan(PIP2B)Provinsi Kalimantan Tengah masih belum memadai, terlihat dari beberapa temuan dalam penelitian sehingga proses pelaksanaan penyelesaian pekerjaan menjadi terhambat. Hal ini tidak sejalan dengan teori yang dikemukakan H.A.S. Moenir (2002: 88) dalam bukunya manajemen pelayanan Umum di Indonesia mengatakan ada 6 (enam) faktor pendukung pelayanan, yaitu diantaranya yaitu faktor sarana pelayanan yang berfungsi untuk mempercepat proses pelaksanaan pekerjaan sehingga dapat menghemat waktu, meningkatkan produktivitas baik barang atau jasa, ketetapan susunan yang baik dan terjamin, menimbulkan rasa nyaman bagi orang yang berkepentingan serta menimbulkan perasaan puas pada 
orang-orang yang berkepentingan sehingga dapat mengurangi sifat emosional.

\section{KESIMPULAN}

I. Sarana dan prasarana yang masih belum memadai terlihat minimnya fasilitas yang diberikan, serta komunikasi yang kurang terjalin antara pihak Kantor Pusat Informasi Pengembangan Permukiman dan Bangunan (PIP2B) dengan Kementerian PUPR Pusat, sebagai berikut :

a. Kurangnya ketersediaan tempat duduk di ruang tunggu di Kantor Pusat Informasi Pengembangan Permukiman dan Bangunan (PIP2B.

b. Tidak adanya papan informasi yang terpasang pada ruangan pelayanan.

c. Tidak adanya pendingin ruangan ataupun kipas angin Untuk mendinginkan ruangan yang pengap.

d. PC computer dan printer yang terbatas

e. Petugas pelayanan tidak lengkap.

f. Belum adanya realisasi terhadap pengadaan sarana dan prasarana Kantor Pusat Informasi Pengembangan Permukiman dan Bangunan (PIP2B).

2. Faktor penghambat yang menyebabkan Pusat Informasi Pengembangan Permukiman dan Bangunan (PIP2B) Provinsi Kalimantan Tengah dikarenakan sebagai berikut:

a. Proses penanganan dari Kementerian Pusat yang sedikit lambat merespons dengan Pusat Informasi Pengembangan Permukiman dan Bangunan (PIP2B) Provinsi Kalimantan Tengah yang membuat masyarakat mengeluh lamanya penanganan.

b. Segala macam jenis peralatan, perlengkapan kerja dan fasilitas yang berfungsi sebagai alat pendukung utama dalam mempercepat pelaksanaan penyelesaiaan pekerjaan terbatas.

\section{REFERENSI}

Harbani, Pasolong. 20I3. Teori Administrasi Publik. Bandung : Penerbit Alfabeta.

Hardiyansyah. 20II. Kualitas Pelayanan Publik. Yogyakarta : Gava Media.

Moenir, H.A.S. 2002. Manajemen Pelayanan Umum di Indonesia. Jakarta : Bumi Aksara.

Rahmayanti, Nina. 2010. Manajemen Pelayanan Prima. Yogyakarta : Graha Ilmu.

Sinambela, Lijan Poltak, dkk. 20I I. Reformasi Pelayanan Publik. Jakarta: PT. Bumi .

Pandji, Santosa 2008. Adminstrasi Publik. Bandung : Refika Aditama.

Peraturan Pemerintah Nomor 96 tahun 2012 tentang Pelaksanaan Undang-undang Nomor 25 tahun 2009 tentang Pelayanan Publik.

Sujardi. 2009. Pengembangan Pelayanan Publik. Bandung: PT. Refika Aditama.

Wahyudi, Kumorotomo. 200I. Etika Administrasi Publik. Jakarta : PT. Raja Grafindo Persada. 